\section{Not so 'nuclear free'}

\section{Washington}

UNTIL last week, the city of Oakland, California, was off limits to nuclear weapons, materials and reactors. City officals were banned from doing business with companies that participated in nuclear-weapons production, a list that included IBM, General Electric and Monsanto. Known as a nuclear-free zone, Oakland's ordinance was considered the strongest of the similar laws in 169 other US cities. But last week a California judge ruled that Oakland had gone too far. In a legal setback to the growing nuclear-free movement, the court ruled that the city's ordinance is unconstitutional.

City officials say they will appeal the decision, opening the way for a possible precedent-setting ruling by a higher court.

Federal agencies have joined the fray as well. Oakland is on a major supply route for the Lawrence Livermore National Laboratory, the main Department of Energy (DOE) nuclear weapons research facility. Several military bases located in the city also have the capability of housing nuclear weapons.

The case made headlines last year when the US Justice Department submitted an unsolicited opinion on the matter, finding that the law violated the US constitution. Local communities cannot restrict the government's ability to provide for the national defence and regulate nuclear energy, the US lawyers said.

Anti-nuclear activists charged that the administration had given in to a concerted lobbying campaign by the nation's defence contractors. In March they released leaked documents that showed that, before the justice department opinion, the Aerospace Industries Association, a Washington-based trade group, had met with the secretary of defence to urge opposition to the nuclear-free initiatives.

The association defends the meeting as its "legitimate right to meet with officials from the federal government at any time they are willing to see us". But David Birman, of the Lawyers' Committee on Nuclear Policy, feels that it is "politically very questionable" that the administration would take its first action on a nuclear-free zone (Oakland is just one of many) only after it had been lobbied by industry.

A major legal question in the case, Birman says, is whether federal law can pre-empt local law on nuclear matters. If it cannot, nuclear-free zones stand. But if federal law does take precedence, then by the same argument, international law which bans nuclear weapons - should take even greater precedence, he says.

Next month Alameda County, which includes Lawrence Livermore Laboratory and Oakland, will vote on "Measure A", a wide-ranging initiative that would create a government body to rid the county of all nuclear materials and research. Supporters collected 38,000 signatures last year to put the initiative on the ballot; chances are seen as good that it will pass in June. Over half of the county's residents already live in areas that voted themselves nuclearfree.

Chief target is Lawrence Livermore laboratory, which would be "converted" to purely non-nuclear work such as environmental and health research. Livermore scientists say such a move would effectively close the $\$ 1,000$ million laboratory. A third of the laboratory's current research is related to nuclear weapons, and another third has some nuclear aspect. The removal of nuclear work would be phased over a five-year period, but DOE would almost certainly sue to stop the county from tampering with the laboratory.

Defence contractors and private citizens have assembled a coalition to fight the initiative. Called the Citizens for Fiscal and Economic Responsibility, the group has already raised over a quarter of a million dollars. Last week's court decision on the Oakland ban is not expected significantly to affect the vote. But if the case goes to the Supreme Court, as some now predict it will, the Alameda initiative, as well as nuclear-free zones throughout the United States, may hang in the balance.

G. Christopher Anderson

\section{GENOME PROJECT}

\section{Howard Hughes gets HUGO off the ground}

\section{Washington}

Two years after it was founded, the Human Genome Organization (HUGO) has finally garnered its first funding of note. The Howard Hughes Medical Institute (HHMI) last week announced a \$1 million, grant, spread over four years, to support HUGO's efforts to promote and coordinate international collaboration in mapping and sequencing the human genome.

A matching grant is expected to be announced soon by Burroughs Wellcome. With over $\$ 500,000$ a year at its disposal, HUGO's first step will be to set up permanent offices (in Bethesda, Maryland, in London and in Osaka), and begin the work of helping to organize the 15 -year $\$ 2,000$ $\$ 3,000$ million genome initiative.

Without major funding, HUGO has so far been more concept than reality. But genome researchers hope that new grants will finally allow HUGO to take an active role in coordinating the exchange of data, samples and technology.

G. Christopher Anderson

\title{
Frankfurt
}

THE West German grant agency, DFG (Deutsche Forschungsgemeinschaft) began laying out a common German research policy last week when it proposed supporting basic research in a unified Germany "from a single pot". The plan, which was unanimously approved by the DFG Senate, must still receive political approval from Bonn, East Berlin and Länder governments before it can take effect, probably not before 1991. DFG's constitution prevents it from providing research support for anyone outside West Germany except under special circumstances.

DFG is the first research organization in the West to announce its plans for East Germany, and if other organizations take a similar approach, the withering away of the East German Academy of Sciences is bound to follow.

DFG will stick to its principles of peerreviewed and performance-based funding in supporting research in East Germany, according to spokeswoman Eva-Maria Streier. The consensus in the Senate, she reports, was "not to budge even half an inch" in applying the same high standards to East and West German research proposals.

Significantly, the DFG plan does not exclude applications from individual researchers in academy institutes. Although DFG generally declines grant applications from West Germans working at Max Planck institutes or GFEs (the Large Research Establishments) unless the project falls outside the normal scope of these institutes, DFG will give all applications from academy researchers a chance. But providing researchers' salaries or entire institute budgets is out of the question, she said.

The DFG plan addresses only indirectly the burning question about the fate of the academy, the largest and most important scientific institution in East Germany, whose budget of 1,000 million East German marks is due to run out at the end of this year.

Western observers estimate that between one-fourth and one-third of the academy's "research" belongs in industry or in applied research institutes similar to the West German Fraunhofer Institutes. But the fate of the other researchers - the cream of the crop in a country that has fallen far behind the West in the past ten years - is still entirely up in the air.

Dieter Simon, the chairman of the influential science advisory council Wissenschaftsrat and a permanent observer in the DFG Senate, warns that if the DFG plan is applied rigorously, "no one in East 